\title{
Qualification of independent spent fuel storage installation ${ }^{\text {is }}$
}

\author{
Larry E. Fischer ${ }^{\mathrm{a}, *}$, Allen Howe ${ }^{\mathrm{b}}$ \\ a Applied Research Division, Lawrence Livermore National Laboratory, PO Box 808, L-641, Livermore, CA 94551, USA \\ ${ }^{\mathrm{b}}$ Spent Fuel Projects, US Nuclear Regulatory Commission, Washington DC 20555, USA
}

\begin{abstract}
This paper describes the qualification process of a typical independent spent fuel storage installation (ISFSI). It provides background information regarding the licensing and history of ISFSIs. It discusses the process for obtaining a general ISFSI license. A typical ISFSI with its dry cask storage system (DCSS) is described. A description is presented of a typical confirmatory action taken on a DCSS to assure adequate qualification and full compliance of the system with Federal regulations. (C) 1999 Published by Elsevier Science S.A. All rights reserved.
\end{abstract}

\section{Introduction}

An independent spent fuel storage installation (ISFSI) is a complex designed and constructed for the interim storage of spent nuclear fuel and other radioactive materials associated with spent fuel storage. It is a solution to extend the storage capacity for spent fuel at a reactor site that lacks sufficient spent fuel pool (SFP) storage capacity. Essentially all licensed ISFSI designs utilize dry

\footnotetext{
This paper was prepared as an account of work sponsored by an agency of the United States Government. Neither the United States government nor any agency thereof, nor any of their employees, makes any warranty, expressed or implied. or assumes any legal liability or responsibility for any third part's use, or the results of such use, of any information, apparatus, product. Or process disclosed in this paper, or represents that its use by such third party would not infringe privately owned rights. The views expressed in this paper are not necessarily those of the US Nuclear Regulatory Commission.

* Corresponding author. Tel.: + 1-925-423-0159; fax: + 1925-423-4145.

E-mail address: fischer3@llnl.gov (L.E. Fischer)
}

cask storage systems (DCSS) that provide confinement, radiological shielding, physical protection, and inherently passive cooling of their spent nuclear fuel during normal, off-normal, and accident conditions. A typical ISFSI consists of several DCSSs arranged on a reinforced concrete pad in a secured area within the physical boundary of a nuclear power plant.

This paper presents:(1) background information regarding the licensing and history of ISFSIs; (2) a discussion of the process for obtaining a general ISFSI license; (3) descriptions of a typical ISFSI and DCSS; and (4) a description of a typical confirmatory action taken on a DCSS to assure adequate qualification and full compliance of the system with Federal regulations.

\section{Background}

Most US nuclear power plant SFPs were not originally designed with a storage capacity for all 
the spent fuel generated over the operating life by their reactors. Utilities originally planned for spent fuel to remain in the SFP for a few years after discharge, and then to be sent to a reprocessing facility. However, the US Government declared a moratorium on reprocessing in 1977. Although the ban was later lifted, reprocessing was eliminated as a viable option. Consequently, utilities expanded the storage capacity of their SFPs by using high-density storage racks. This has been only a short-term solution and many utilities have reached, or will soon reach, their SFP storage capacity.

Utilities now plan to eventually ship their spent fuel to a geologic repository operated by the US Government. The Nuclear Waste Policy Act of 1982, as amended (NWPA) requires the US Department of energy (DOE) to begin accepting spent fuel for permanent disposal by 1998. However, the federal repository still remains in the planning stages, and will not be able to accept spent fuel by 1998. A new date $(\sim 2010)$ has been proposed as the year when the repository will be opened. As there is no other federal management option, US utilities have developed ISFSIs as a means for expanding their spent fuel storage capacity on an interim basis.

ISFSI regulation was originally governed by 10 CFR Part 70 'Domestic Licensing of Special Nuclear Material' Code of Federal Regulations, 1979. In 1974, the Atomic energy Commission (predecessor of the NRC) issued a regulatory guide on storage of spent fuel in ISFSIs, Regulatory Guide 3.24 'Guidance on the License Application, Siting, Design, and Plant Protection for an Independent Spent Fuel Storage Installation', which then supported 10 CFR Part 70. The need for regulation to specifically address spent fuel storage was supported by the 'Final Generic Environmental Impact Statement [GEIS] on Handling and Storage of Spent Light Water Power Reactor Fuel' (Code of Federal Regulations, 1979). In GEIS, the staff predicted that additional storage capacity outside reactor storage basins would be needed, conservatively assuming that neither reprocessing facilities nor a geologic repository would be available before the year 2000. In November 1980, the NRC issued 10 CFR Part 72
'Licensing Requirements for the Storage of Spent Fuel in an Independent Spent Fuel Storage Installation', superseding 10 CFR Part 70 and Regulatory Guide 3.24 with respect to the regulation of spent fuel storage in ISFSIs (Code of Federal Regulations, 1998).

The NRC developed 10 CFR Part 72 specifically for spent fuel storage outside reactor storage basins. The regulations covers both wet and dry storage systems for site-specific ISFSIs that can be located either at reactor sites or away from them. Therefore, an ISFSI license is a materials license and not a facility license. It requires one-step licensing, in which it is not necessary to first obtain a construction permit and then an operating license, as is required for a power reactor facility license. In a sense, the Part 72 license is, for power reactor licensees, a renewal of authorization to receive and store spent fuel, which had previously been granted under the general regulations 10 CFR Parts 30 and 40, and in particular 10 CFR Part 70 'Domestic Licensing of Special Nuclear Material'. The renewal license period under 10 CFR Part 72 is 20 years.

The requirements for licensing, either for a site-specific or for a general ISFSI, are in $10 \mathrm{CFR}$ Part 72. This paper discusses only the licensing process for an ISFSI established by a general license. As required by the Nuclear Waste Policy Act of 1982, the NRC established, by rule, a process to provide for storage of spent fuel on the sites of nuclear power reactors without the need for additional site-specific commission approvals. In the rule, $10 \mathrm{CFR} 72.210, \mathrm{NRC}$ issued a general license for the storage of spent fuel at an ISFSI at power reactor sites to persons authorized to possess or operate a nuclear power reactor licensed under $10 \mathrm{CFR} 50$. The general license is limited to storage of spent fuel in casks approved under the provisions of 10 CFR Part 72, Subpart L. The following conditions apply to the general license:The licensee must perform written evaluations which establish that:

1. The conditions of the certificate of compliance have been met in accordance with 10 CFR 72.212 (b).

2. The cask storage pads and areas have been adequately designed. 
3. The criteria for radioactive materials in effluents and direct radiation have been met in accordance with 10 CFR 72.104 .

These conditions entail verification that the reactor site parameters, such as extreme temperatures, seismic design criteria and wind velocities are enveloped by the DCSS design bases.

Within the existing framework of the programs established by its 10 CFR 50 license for reactor operation, general licensees must also perform, evaluate, modify, and/or prepare written operating procedures and training modules, a preoperational testing and training exercise, identification of any unreviewed safety questions, protection from radiological sabotage, the reactor emergency plan, and ISFSI surveillance requirements. The general licensee must notify the NRC at least 90 days preceding first-time storage of spent fuel under the general license, and must register the use of each cask with the NRC no later than 30 days after storing spent fuel in that cask.

Dry storage casks that have been issued a certificate of compliance are listed in 10 CFR 72.214 'List of approved spent fuel storage casks'. The certificate of compliance for the cask is valid for 20 years. The applicant must submit to the NRC an application containing a safety analysis report (SAR). Once the application is received by the NRC, a docket number is assigned and the application is made available for public inspection. The NRC reviews the vender's SAR, prepares a draft safety evaluation report (SER), a draft environmental assessment (EA), and a draft certificate of compliance, and publishes a notice of proposed rulemaking to amend 10 CFR 72.214 in the Federal Register (FR). All documents relied upon for the proposed rulemaking are made publicly available, and a period is then opened for public comment. After reviewing the public comments, the NRC prepares the final SER, final EA, and final certificate of compliance. The resolution of comments and final rulemaking to add the cask to the list of approved casks is published in the FR along with the effective date of the final rule (usually 30 days after publication). The NRC then issues the final SER and certificate of compliance, with its technical specifications for the cask to the cask vendor.

\section{Descriptions of typical ISFSI and DCSS}

ISFSI sites currently storing fuel under the general license authorized by 10 CFR Part 72, Subpart K are identified in Table 1 (Nuclear Regulatory Commission, 1996). All power reactor licensees have been given a general license to store fuel in a DCSS that has received a certificate of compliance from the NRC.

One typical site, the Palisades, ISFSI employs the VSC-24, designed by Sierra Nuclear Corporation. The ISFSI currently has thirteen loaded casks.

The Palisades Nuclear Power Plant, owned and operated by the Consumers Power Company of Michigan (CPC), loaded its first cask in May 1993. Palisades was the first utility to utilize the revised 10 CFR Part 72 that authorized the general license.

In April 1993, the general license approval was challenged by the Michigan Attorney General and Lake Michigan Federation citizen organization on the grounds that the licensing process should have entailed a full EIS rather than the less-detailed EA. The US District Court for Western Michigan denied the request to prevent cask loading, and

Table 1

General license ISFSI sites storing spent fuel

\begin{tabular}{llll}
\hline ISFSI & Operator & First loading date & DCSS \\
\hline Arkansas Nuclear One & Energy operations & $12 / 96$ & VSC-24 \\
Davis-Besse & Toledo Edison Company & $01 / 96$ & Standardized NUHOMS-24P \\
Palisades & Consumers Power Company & $05 / 93$ & VSC-24 \\
Point Beach & Wisconsin Electric Power Company & $12 / 95$ & VSC-24 \\
\hline
\end{tabular}




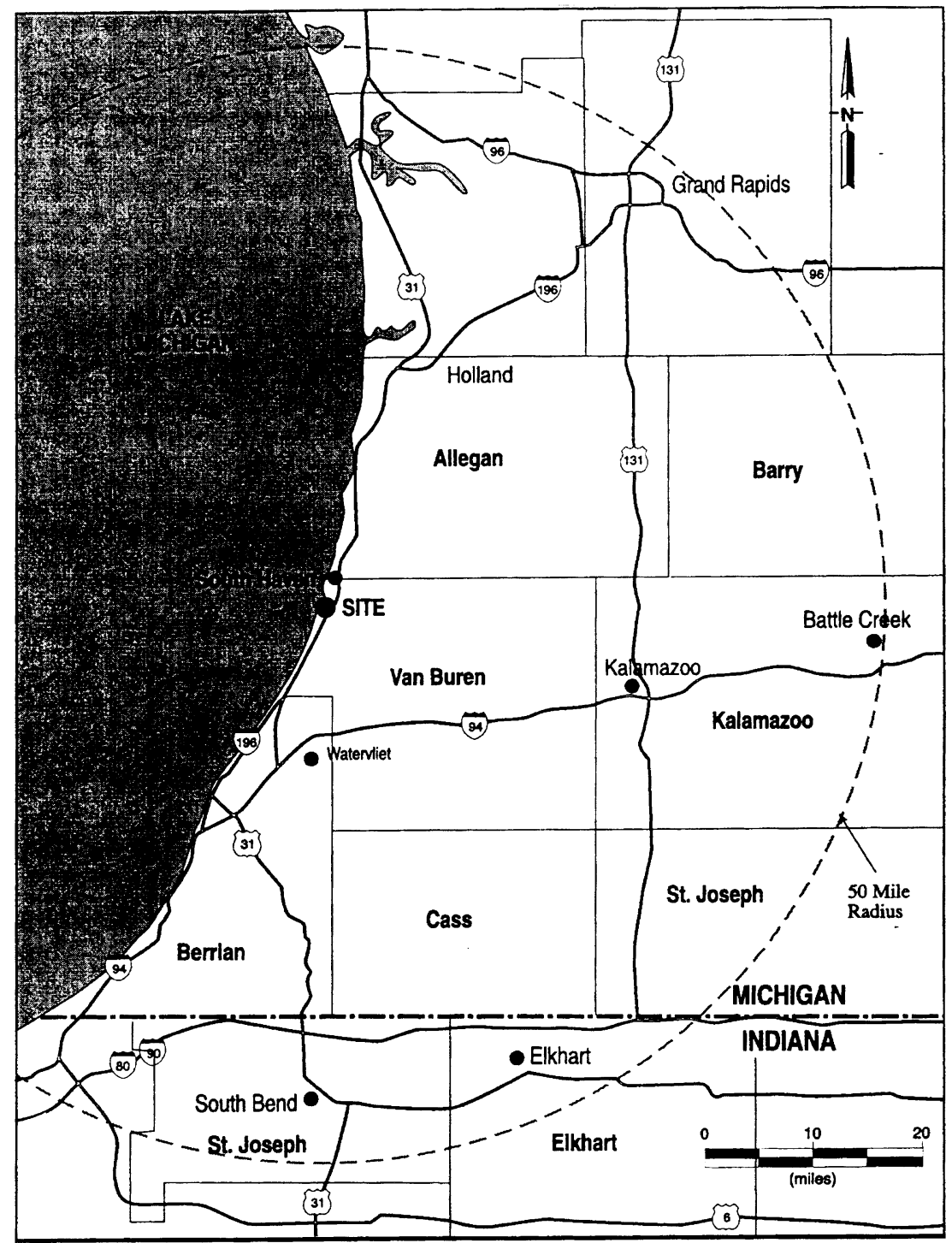

Fig. 1. The Palisades nuclear power plant.

the denial was ultimately upheld by the US Supreme Court.

As shown in Fig. 1, the Palisades Nuclear Power Plant is located on the eastern shore of Lake Michigan in Van Buren County, Michigan. The location of the ISFSI in relation to the site is shown in Fig. 2.

The ventilated storage cask system (VSC-24), made by Sierra Nuclear Corporation, is a concrete DCSS designed to vertically store 24 PWR spent fuel assemblies. The principal components of the system are a steel multi-assembly sealed basket (MSB), a ventilated concrete cask (VCC), and an MSB transfer cask (MTC). The VSC-24 is currently used at Palisades, Point Beach, and Arkansas Nuclear One. A diagram of the cask is shown in Fig. 3.

The MSB is shown in Fig. 4. The MSB consists of a steel cylindrical shell with a thick shield plug and steel cover plates welded at each end. The 
shell length is fuel-specific and varies from 4.1 to $4.6 \mathrm{~m}(13.8-15.1 \mathrm{ft}$.), the diameter is $1.6 \mathrm{~m}(5.3$ $\mathrm{ft}$.), and the shell thickness is $2.5 \mathrm{~cm}$ (1 in.). The MSB weighs $\sim 29$ tonnes (32 tons). The internal steel basket consists of a welded structure with 24 square storage locations. The basket aids in the insertion of the fuel assemblies, enhances subcriticality during loading operations and provides structural support during a potential drop accident.

The VCC is a reinforced-concrete cask in the shape of a hollow right circular cylinder. The VCC has four penetrations for air entry (located at the bottom of the VCC) and four outlets located at the top. The penetrations are protected from debris intrusion by wire mesh screens. The internal cavity of the VCC as well as the inlets and outlets are steel lined. After the MSB is inserted, a shield ring is placed over the MSB/ VCC gap and the cask weather cover is installed. The VCC height is fuel-specific and varies from 5.0 to $5.4 \mathrm{~m}$ (16.4-17.7 ft.) high. The outer diameter is $\sim 3.4 \mathrm{~m}(11.2 \mathrm{ft}$.), and the walls consist of $70 \mathrm{~cm}$ (29 in.) thick concrete and a $4.5 \mathrm{~cm}(1.75$ in.) thick steel liner. Total weight of the VCC and MSB (loaded and with lids) is 121 tonnes (133 tons).

The MTC is a shielded lifting device with inner and outer structural steel cylinders which house lead and solid RX-277 neutron shield cylinders designed to reduce radiation from the fuel inside the MSB/MTC. The MTC functions to transfer the MSB from the spent fuel pool to the VCC inside the fuel pool building.

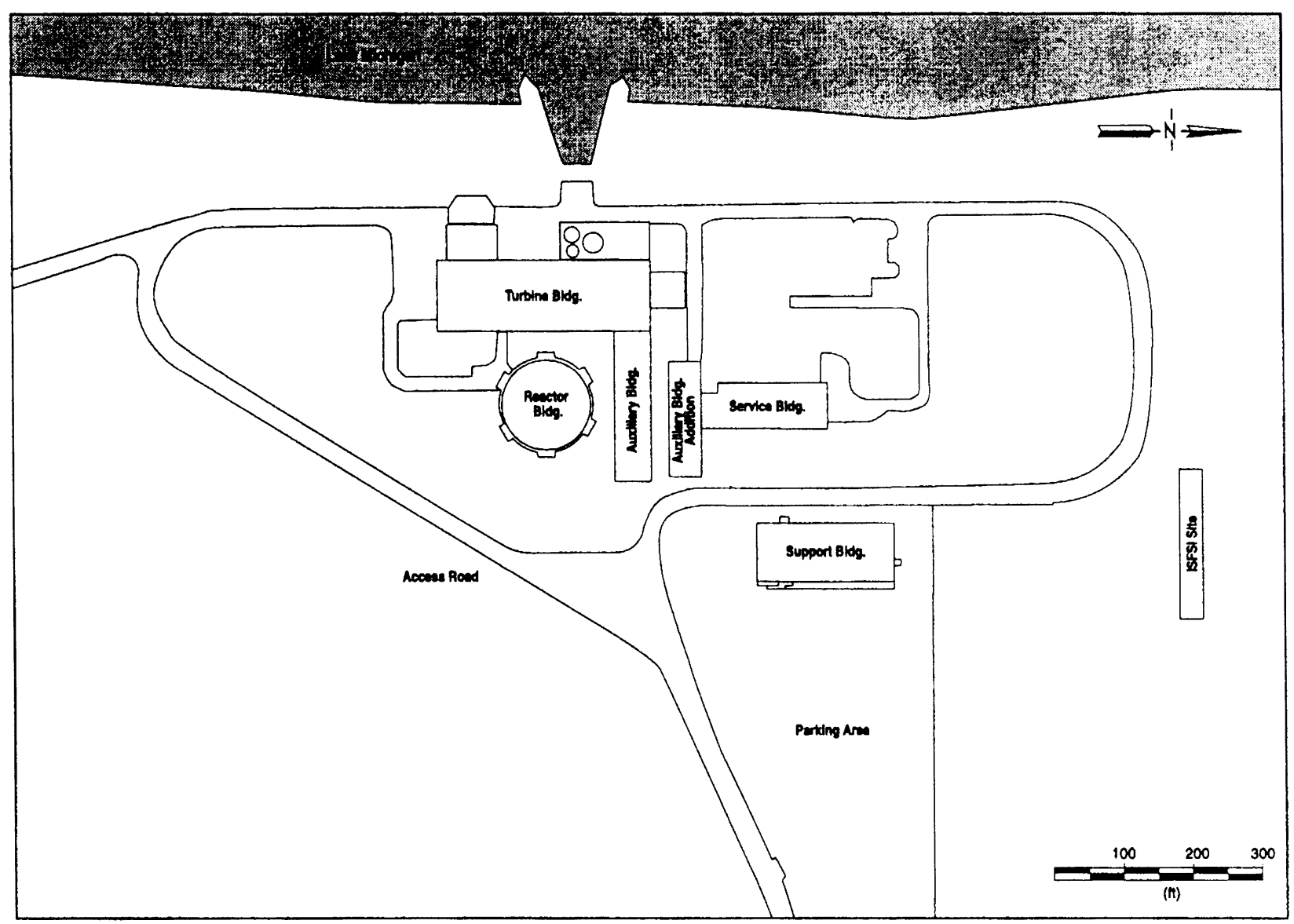

Fig. 2. The location of the ISFSI in relation to the site. 


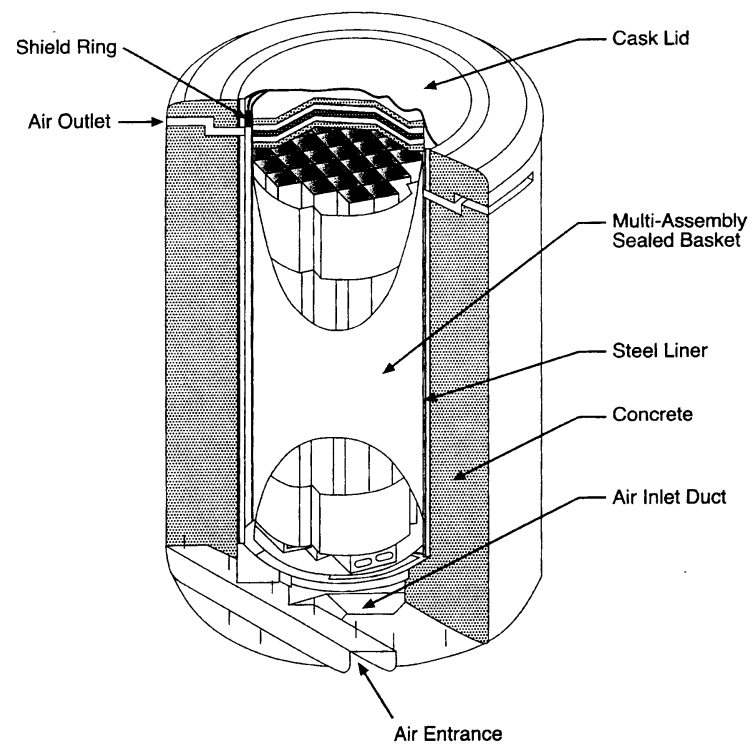

Fig. 3. A diagram of the cask.

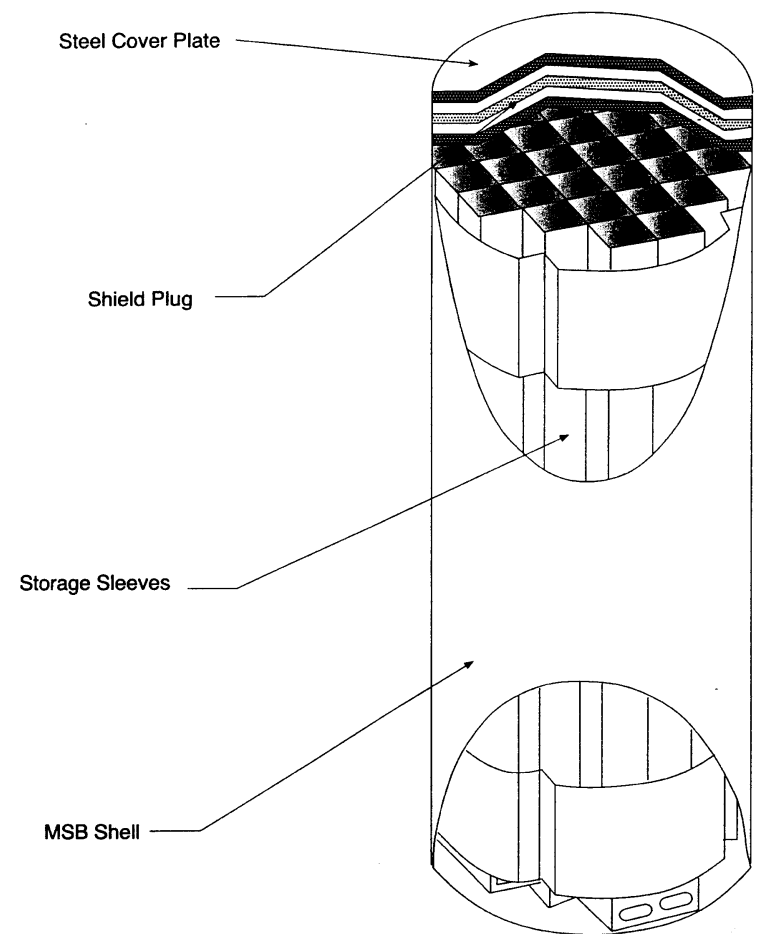

Fig. 4. The MSB.

\section{Confirmatory action}

In addition to formal enforcement actions, NRC employs administrative actions such as Confirmatory Action Letters (CALs) to supplement its enforcement program. CALs are letters
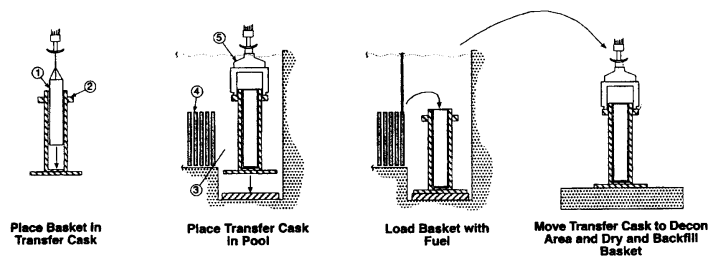

VCC and MSB are transferred to the concrete pad.

The decay heat is removed passively by natural draft convection. Air enters the lower part of the $\mathrm{VCC}$, rises around the MSB, and exits through the top. The system is self regulating, and the only required maintenance is the periodic inspection of the air inlet and outlet screens to ensure that they have not been blocked by debris. Normal radiation monitoring is also performed.

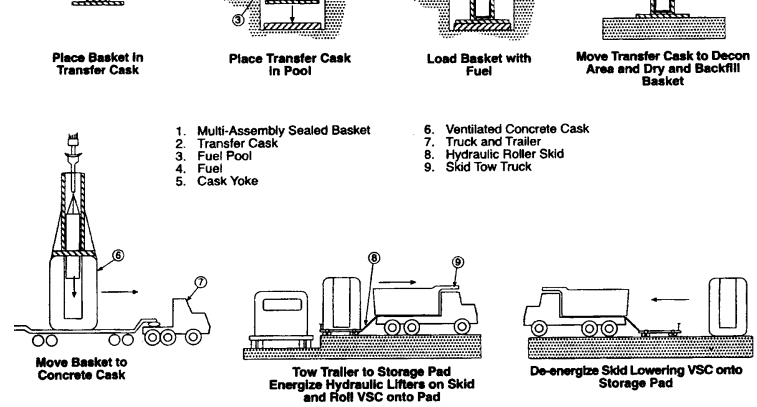

Fig. 5. Major steps in handling/transfer of fuel. 
confirming a licensee's or contractor's agreement to take certain actions to remove significant concerns about health and safety, safeguards, or the environment.

\subsection{Confirmatory action letter}

Upon the identification of a significant concern about health and safety, safeguards, or the environment, a CAL is issued to document or confirm commitments or corrective actions from the certificate holder or licensee. The following paragraphs are modified excerpts from a typical CAL.

The US Nuclear Regulatory Commission staff inspected your facility and two of your fabrication contractor facilities. Your corporation holds a Certificate of Compliance for a dry storage cask with identified problems. This inspection focused on welding problems with the dry storage casks used at three nuclear power plants. The problems were in the welds joining the cask shield lid to the spent fuel storage basket (SFSB). NRC is concerned about the difficulties encountered with the welds joining the shield lid to the SFSB, since this weld is part of the confinement boundary of the cask. Furthermore, the weld between the SFSB and the structural lid may be susceptible to the same failure mechanisms as the shield lid weld. It is possible that these particular weld cracks may not develop until after cask welds have undergone non-destructive examination. Although such weld failures would not pose an off-site threat to public health and safety, such an occurrence would cause the loss of the helium atmosphere inside the SFSB. This condition could result in fuel cladding degradation and future fuel handling and retrievability problems. The scope and depth of the problem may have far-reaching generic implications regarding the continued viability of the cask for dry spent fuel storage. until this issue is resolved, any additional fabrication of cask SFSBs and lid components will be at your own risk.

The inspection revealed that neither your corporation nor the user licensees had performed a comprehensive root-cause analysis of the first two weld problems. An understanding of the root cause is essential to preventing recurrence when welding future casks, and to assessing the possibil- ity of additional weld problems, perhaps undetected or delayed, in loaded casks. Subsequently, NRC held a public meeting with your corporation representatives to discuss your corporation's implemented and planned actions in response to the weld problems and inspection findings. As stated at this meeting, the staff remains concerned that that the root cause(s) of the weld problems have not been conclusively determined. Accordingly, the staff understands that you will take the following actions:

1. Determine the root cause(s) of the weld problems;

2. Assess the potential for delayed cracking in the shield and structural lid welds in the 19 casks presently in use;

3. Determine appropriate corrective actions to inhibit recurrence of weld problems; and

4. On completion of this action, you will submit to the Director, Office of Nuclear Material Safety and Safeguards, a written description of the evaluations described in Items 1, 2, and 3. A copy of the submittal should be sent to Director, Spent Fuel Project Office. (You may include in this response the information required by item 2 below, confirming all the actions required by items $1-2$ above.)

You will also:

1. Notify me immediately if your understanding differs from that set forth above;

2. Notify me if for any reason you cannot complete the actions within the specified schedule and advise me in writing of your modified schedule in advance of the change; and

3. Notify me in writing when you have completed the actions addressed in this Confirmatory Action Letter.

After we receive your letter describing the results of your actions, we will contact you to arrange a mutually acceptable date to meet and discuss the results of your corporation's activities.

Issuance of this Confirmatory Action Letter does not preclude issuance of an order formalizing the above commitments or requiring other Certificate-holder actions; nor does it preclude NRC from taking enforcement action for violations of NRC requirements that may have prompted the issuance of this letter. In addition, 
failure to take the actions addressed in this Confirmatory Action Letter may result in enforcement action.

In accordance with 10 CFR 2.790 of the NRC's 'Rules of Practice', a copy of this letter and your response will be placed in the NRC Public Document Room (PDR). To the extent possible, your response should not include any personal privacy, proprietary, or safeguards information, so that it can be placed in the PDR without redaction. However, if you find it necessary to include such information, you should clearly indicate the specific information that you desire not to be placed in the PDR, and provide the legal basis to support your request for withholding the information from the public.

\subsection{Confirmatory action letter closure}

A CAL closure letter is prepared by the NRC to document the closure of action items and the agreed upon implementation to correct the problems. The following are modified excepts from the NRC CAL closure letter that document the final dispositions on the weld crack problem.

\subsubsection{Determine the root causes of the weld problems}

The cask vendor and licensee using the casks (Owners Group) reviewed a total of four cracking events and their root causes. The staff reviewed information submitted by the Owners Group regarding the first power plant crack and additional information gathered during a site visit. The additional information included a condition report evaluation which provided a description of the crack and the results of examinations performed by the general licensee. In addition, the staff reviewed photomicrographs of metallurgical samples taken from the area excavated to remove the crack. The Owners Group concluded that the weld crack propagated along prior austenite grain boundaries of a pre-existing weld of unknown origin (the welds had not been documented during fabrication). The existence of undocumented welds observed on several SFSB shells was confirmed as discussed in NRC inspection reports. The staff accepted the Owners Group conclusion that there was evidence of a pre-existing weld of unknown origin and that the weld crack may have propagated along prior austenite grain boundaries of that preexisting weld.

The staff reviewed the evaluation of the causes of the second crack discovered during welding of the structural lid. Based on this information and the staff's experience, the staff found that the wide fit-up gaps and a resulting lack of fusion in the weld metal were a reasonable explanation for the cracks observed between weld beads on the root pass of the structural lid-to-shell weld. The staff also concluded that a probable cause for the cracking and porosity found in the structural lid-to-shield lid seal weld was contamination of the weld by moisture.

The staff reviewed the information submitted by the Owners Group regarding the third and fourth cracks observed on SFSBs and additional information gathered by NRC during inspection. The results of the inspections are documented. Data reviewed included a photograph of the third crack observed in December 1996, photomicrographs of the fourth crack observed in March 1997, and root cause analysis reports, prepared by two separate consultants. Based on the information reviewed and professional experience, the staff concluded that the second crack at the second power plant appears to have been hydrogen induced cracking (HIC). The staff also concluded that there are insufficient data to further evaluate the cause of the first crack at the second power plant, but believes that this crack may have been HIC. The staff concluded that the root causes presented by the Owners Group for the weld cracking events were credible.

\subsubsection{Assess the potential for delayed cracking in} the shield and structural lid welds in the 19 casks presently in use

The staff reviewed information provided by the Owners Group and independently reviewed additional literature regarding HIC. The staff accepted the three principal factors that promote HIC discussed by the cask Owners Group. Specifically, the staff accepted:

- The hydrogen content of the welding consumables, was high enough to cause these welds to be susceptible to HIC. 
- The microstructure and the chemical compositions, especially those for steel plates with the higher computed values of carbon equivalent (CE), are within the range of compositions for which cracking could likely occur at the expected hydrogen levels.

- Moderately-high to high restraint in the weld joints could have promoted cracking in these weldments.

The staff identified additional factors that may increase or decrease the potential for HIC of the SFSB closure welds:

- The level of sulfur in the steels may affect the potential for HIC. Many of the lid closure weldments involved low-sulfur steels. these low-sulfur steels, especially those with shape controlled sulfides, have superior fracture toughness and may have a decreased susceptibility to HIC, when compared with that for steels of higher sulfur content but at the same value of $\mathrm{CE}$.

- The hydrogen content may vary widely in weldments made without strict controls on selected weld parameters. As indicated previously, welds with high hydrogen content may be susceptible to HIC.

- Poor fit-up can lead to increases in local notch effects and higher local stresses.

- Welding processes differ in cooling rates and therefore in heat affected zone (HAZ) microstructures. The local maximum levels of hardness can be decreased by tempering in multi-pass weldments and this can decrease the susceptibility of cracking by hydrogen.

- A lower temperature of the weldments could increase the propensity for HIC. Factors that would have decreased temperatures of weldments include lower temperatures in the spent fuel pool and lower decay heat from the spent fuel.

The staff concluded that conditions that promote HIC may have existed during the welding of previously loaded casks and, therefore, weldments of both the structural lid and the shield lid on those casks may have been susceptible to HIC. Cask closure welds on SFSBs with low sulfur content in the steel may be less susceptible to HIC than steels of higher sulfur content.
Regarding delay times for HIC of SA-5 16, Grade 70 steels, the staff accepts many of the factors that affect delay times described by the Owners Group. however, the staff does not accept the owners Group estimate of $3 \mathrm{~h}$ as the maximum delay time for cracking. While the staff concluded that the initiation of cracks of significant size would most probably have been within the 3-h delay time, estimated by the Cask Owners Group, the staff determined that cracking may have occurred over longer time periods.

For the previously loaded SFSBs, the staff concluded that hydrogen-induced delayed cracking behavior could have occurred both before and after completion of weld inspections required by the certificate of compliance. In addition, the staff concluded that cracking through the weld would only occur in the most severe cases of HIC. As discussed in the corrective actions, the Owners Group will volumetrically inspect, using ultrasonic test (UT), the structural lid welds of the previously loaded (and future loaded) SFSBs.

\subsubsection{Determine appropriate corrective actions to inhibit recurrence of weld problems}

The staff reviewed the information provided by the Owners Group and independently evaluated the proposed corrective actions related to the weld cracking. The corrective actions described in Table 2 are based on the root causes identified for the known instances of cracking.

The four corrective actions for the first root cause, defects in shell material and undocumented welds, are based on identifying defects present in the SFSB wall or preventing undocumented welds. Referencing the Corrective Actions (CA) in Table 2, CA 1 (acid etching) will identify undocumented welds and CA 2 (UT examination of the base material) will identify material defects and thus allow them to dispositioned or removed and repaired before SFSB loading. CA 3 (certification of SFSBs) ensures an added level of oversight to verify the SFSB fabrication process met requirements and commitments. CA 4 (use of low sulfur, calcium-treated, vacuum-degassed steel) is a preventive measure to improve: (1) the throughthickness mechanical properties of the steel, important for the residual stress loading during 
Table 2

Owners group corrective actions for unloaded SFSBS and SFSBs to be manufactured in the future

\begin{tabular}{|c|c|c|}
\hline Root cause & Corrective action & Applicability \\
\hline \multirow[t]{4}{*}{$\begin{array}{l}\text { Defect in shell material; } \\
\text { undocumented welds }\end{array}$} & 1. Acid etch top 4 in. of cask & $\begin{array}{l}\text { 1-2. Unloaded SFSBs already } \\
\text { manufactured }\end{array}$ \\
\hline & 2. UT per ASTM A435 & \\
\hline & $\begin{array}{l}\text { 3. Certification that SFSBs meet the design and } \\
\text { terms and conditions of the CoC and are in } \\
\text { conformance with the Safety Analysis Report } \\
\text { and Safety Evaluation Report including any } \\
\text { referenced standards, criteria, or requirements }\end{array}$ & 3. Unloaded SFSBs \\
\hline & $\begin{array}{l}\text { 4. Use of low sulfur, calcium-treated, } \\
\text { vacuum-degassed steel }\end{array}$ & 4. SFSBs manufactured in the future \\
\hline \multirow{2}{*}{$\begin{array}{l}\text { Improper fit-up of lid and backing } \\
\text { ring }\end{array}$} & 5. Proper fit-up of assembly & 5-6. All future lid welding \\
\hline & $\begin{array}{l}\text { 6. Manual welding to fill-in unacceptable gaps } \\
\text { before automated welding }\end{array}$ & \\
\hline \multirow[t]{2}{*}{ Moisture contamination } & $\begin{array}{l}\text { 7. Ensure water level in SFSB is adequately } \\
\text { below the shield lid via partial drain of SFSB }\end{array}$ & $\begin{array}{l}\text { 7-9. All future shield and structural } \\
\text { lid welding, including lid-to-lid and } \\
\text { valve cover fillet welds }\end{array}$ \\
\hline & $\begin{array}{l}\text { 8. Vent or inert airspace beneath shield lid } \\
\text { 9. Preheat weld area to } 200^{\circ} \mathrm{F}\end{array}$ & \\
\hline \multirow[t]{3}{*}{ Hydrogen-induced } & 10. Addition of $200^{\circ} \mathrm{F}$ preheat & $\begin{array}{l}\text { 10-14. All future shield and } \\
\text { structural lid welding, including } \\
\text { lid-to-lid valve cover fillet welds }\end{array}$ \\
\hline & $\begin{array}{l}\text { 11. Addition of } 200^{\circ} \mathrm{F} \text { postheat, } 1 \mathrm{~h} \\
\text { 12. Low hydrogen welding electrodes }(<10 \mathrm{ml} \\
\left.\mathrm{H}_{2} / 100 \mathrm{~g} \text { deposited weld metal }\right)\end{array}$ & \\
\hline & $\begin{array}{l}\text { 13. Large tack welds/balanced weld sequence to } \\
\text { prevent movement of lids and better distribute } \\
\text { shrinkage forces from cooling of weld } \\
\text { 14. 2-h delay before inspection } \\
\text { 15. Use of materials with lower carbon } \\
\text { equivalent values }\end{array}$ & 15 SFSB manufactured in the future \\
\hline
\end{tabular}

closure welding; and (2) fracture toughness properties of the steel, important for the hypothetical drop accident. The staff concluded that the proposed corrective actions for the first root cause provide adequate measures to detect and properly address potential base metal defects or undocumented welds in existing unloaded SFSBs. For SFSBs fabricated in the future, the proposed corrective actions should minimize the potential for base metal defects and undocumented welds.

The two corrective actions for the second root cause, improper fit-up of lid and backing ring, are intended to check proper fit-up (CA 5), and if required, repair by welding to fill in unacceptable gaps (CA 6). These measures serve to reduce the residual stresses generated during cooling of the weld. High residual stresses can distort the structure, exacerbate an existing welding flaw, e.g., propagate a crack, and make a weld more susceptible to HIC. Poor fit-up may also cause weld metal cracking; CA 6 (reducing the root opening by building up the edges with weld metal) is an acceptable remedy for unacceptable gaps. The staff concluded that the proposed corrective actions for the third root cause are adequate to prevent future moisture contamination of welds.

The corrective actions for the fourth root cause, HIC, are preventive measures. The staff evaluated 
the changes to the welding procedures proposed by the Owners Group to address HIC and concluded that these changes will:

- allow hydrogen to diffuse out of base metal before and after welding to reduce susceptibility to HIC (CAs 10 and 11)

- reduce the cooling rate and thus hardness, which reduces susceptibility to HIC (CAs 10 and 11)

- improve fracture and notch toughness (CAs 10 and 11)

- reduce hydrogen introduction into weld metal from electrodes to reduce susceptibility to HIC (CA 12)

- reduce residual stresses to reduce susceptibility to HIC (CAs 10, 11, and 13)

The staff concluded that the Cask Owners Group proposed corrective actions, including modifications to the welding procedures, nondestructive examinations, and other material, quality, and operational changes, were adequate to prevent recurrence of the root causes of the identified welding defects. In addition, volumetric examination of the structural lid-to-shell weld joint will provide reasonable assurance to confirm the presence of a structurally sound weld for both future SFSB loadings and previously loaded SFSBs. The methodology to address flaws identified by UT requires that if unacceptable conditions are identified, the flaws are required to be evaluated and/or repaired in accordance with the licensee's quality assurance program and Owners Group commitments.

The staff concluded that your corporation's proposed revision to licensing documents were acceptable. The staff further concluded that utilities, that are currently using the cask under a general license, must implement the corrective actions contained in Appendices C and D until the affected licensing documents can be updated.

\section{Conclusion}

The Technical Evaluation that summarizes your corporation's final response to the CAL and provides the staff's position regarding the response. In summary, the staff has concluded that your corporation has adequately identified the root causes of the welding problems and developed adequate corrective actions to prevent the recurrence of those root causes. However, the staff also concluded that your corporation did not accurately assess the length of time in which delayed cracking of the shield and structural lid welds may have occurred. In response to this concern, as discussed in the Technical Evaluation, the utilities that currently have casks in use have committed to perform UT of previously loaded casks. The UT data will be used to evaluate whether the casks meet the design basis for the cask structural lid weld.

In addition, your corporation committed that it will submit an amendment request for a Certificate of Compliance to incorporate the corrective actions associated with the welding problems. Specifically, your corporation committed to:

- Update the Safety Analysis Report (SAR) to include 'Ultrasonic examination of the cask structural lid to SFSB'.

- Update the Certificate of Compliance to implement the revised technical specifications.

- Update the SAR to include the corrective actions.

The CAL with its action items is closed effective the date of this letter. However, the corrective actions taken and the implementation of the corrective actions will be subject to NRC review in any future inspections of your corporation and the utilities using the subject cask.

\section{Summary and conclusion}

The qualification of an ISFSI goes beyond obtaining a license. It involves monitoring and inspection of the licensed ISFSI for compliance with its licensed conditions and 10 CFR 72. In those cases where significant concerns arise about compliance, further action, such as a CAL may be issued by NRC to document or confirm commitments or actions by the sites and vendors involved. The action(s) must be brought to closure in a reasonable time and then documented in a CAL Closure Letter that states the closure conditions. As described in this paper, the qualification 
process can be ongoing, particularly during the initial establishment of the ISFSI.

\section{References}

US Code of Federal Regulations, 1979. Licensing Require- ments for the Independent Storage of Spent Nuclear Fuel and High-level Radioactive Waste, Part 70, Title 10, Energy.

US Code of Federal Regulations, 1998. Domestic Licensing of Special Nuclear Materials, Part 72, Title 10, Energy.

US Nuclear Regulatory Commission, 1996. Information Handbook on Independent Spent Fuel Storage Installations, NUREG-1571. 